\title{
Impact of body truck's microclimate on pig skin temperature during pre-slaughter
}

\section{logistics}

\author{
Impacto do microclima do caminhão na temperatura superficial de suínos durante a logística pré- \\ abate
}

Impacto del microclima del camión en la temperatura de la superficie de los cerdos durante la logística pre-sacrificio

\author{
Sivanilza Teixeira Machado \\ ORCID: https://orcid.org/0000-0003-2746-7885 \\ Federal Institute of São Paulo, Brazil \\ E-mail: sivanilzamachado@ifsp.edu.br \\ Irenilza de Alencar Nääs \\ ORCID: https://orcid.org/0000-0003-0663-9377 \\ Paulista University, Brazil \\ E-mail: irenilza.naas@unip.br \\ João Gilberto Mendes dos Reis \\ ORCID: https://orcid.org/0000-0001-6409-2299 \\ Paulista University, Brazil \\ E-mail: joao.reis@docente.unip.br \\ Pedro Luiz de Oliveira Costa Neto \\ ORCID: https://orcid.org/0000-0002-6987-2996 \\ Paulista University, Brazil \\ E-mail: pedroluiz@plocn.com \\ Rodrigo Carlo Toloi \\ ORCID: https://orcid.org/0000-0001-6320-8894 \\ Federal Institute of Mato Grosso, Brazil \\ E-mail: rodrigo.toloi@roo.ifmt.edu.br \\ Rodrigo Couto Santos \\ ORCID: https://orcid.org/0000-0003-4585-9305 \\ Federal University of Grande Dourados, Brazil \\ E-mail: rodrigocouto@ufgd.edu.br \\ Oduvaldo Vendrametto \\ ORCID: https://orcid.org/0000-0003-2430-6138 \\ Paulista University, Brazil \\ E-mail: oduvaldove@gmail.com \\ Arthur Carniato Sanches \\ ORCID: https://orcid.org/0000-0003-2379-0634 \\ Federal University of Grande Dourados, Brazil \\ E-mail: arthursanches@ufgd.edu.br
}

\begin{abstract}
Handling of pigs under hot weather conditions face a critical challenge in meeting thermal comfort and animal welfare standards. Moreover, climate variation affects production and pre-slaughter logistics. This study assesses the thermal comfort of pigs during pre-slaughter procedures under different weather conditions. The case study was conducted at two commercial pig farms in Southeastern Brazil. The bioclimatic index more accurately indicated the pigs' thermal comfort than the temperature-humidity index. The length of the transportation journey critically affected the pigs' thermal comfort, as shown by the rise in pigs' skin temperature $\left(1.56{ }^{\circ} \mathrm{C}\right.$ and $1.64{ }^{\circ} \mathrm{C}$ on pigs from Farm 2 and Farm 1 , respectively). The pigs reached the critical upper limit of the thermoneutral zone under hot weather conditions. Adequate microclimate control during the pre-slaughter management procedures might improve pig welfare. To increase the animals' thermal comfort, both farms should reschedule their transportation to a cooler time of the day. Both farms should also improve their pre-slaughter management processes by training workers to comply with animal welfare requirements and reduce loss.
\end{abstract}

Keywords: Animal welfare; Livestock; Thermal comfort; Truck microenvironment. 


\begin{abstract}
Resumo
O manejo de suínos sob condições de clima quente enfrenta o crítico desafio de atender o conforto térmico e os padrões de bem-estar animal. Considerando ainda, os efeitos da variação climática na produção e na logística pré-abate. Este estudo avalia o conforto térmico dos suínos durante os procedimento pré-abate sob as diferentes condições climáticas. O estudo de caso foi conduzido em duas fazendas comerciais de suínos localizadas na região Sudeste do Brasil. Os resultados do conforto térmico dos suínos foram mais precisos com a utilização do índice bioclimático do que com o índice de temperatura-umidade. A duração da viagem de transporte afetou criticamente o conforto térmico dos suínos, conforme demostrado pelo aumento da temperatura da pele dos suínos $\left(1,56{ }^{\circ} \mathrm{C}\right.$ e $1,64{ }^{\circ} \mathrm{C}$ dos suínos da Fazenda 2 e Fazenda 1, respectivamente). Os suínos alcançaram o limite superior da zona de temperatura em condições de clima quente. Dessa forma, o controle adequado do microclima durante o gerenciamento dos procedimentos pré-abate pode melhorar o bem-estar dos suínos. Para melhorar o conforto térmicos dos animais, ambas as fazendas devem reprogramar as operações de transporte para horários mais frescos do dia. Ambas as fazendas devem também melhorar os processos de gestão pré-abate por meio de treinamentos dos funcionários para cumprir os requisitos de bem-estar animal e reduzir as perdas.
\end{abstract}

Palavras-chave: Bem-estar animal; Pecuária; Conforto térmico; Microambiente de caminhões.

\title{
Resumen
}

El manejo de los cerdos en condiciones de clima cálido enfrenta el desafío crítico de cumplir con los estándares del confort térmico y bienestar animal. También considerando los efectos de la variación climática en la producción y la logística pre-sacrificio. Este estudio evalúa el confort térmico de los cerdos durante el procedimiento pre-sacrificio en diferentes condiciones climáticas. El análisis de caso se llevó a cabo en dos granjas de cerdos comerciales ubicadas en la Región Sudeste de Brasil. Los resultados del confort térmico de los cerdos fueron más precisos con el uso del índice bioclimático que con el índice temperatura-humedad. La duración del viaje de transporte afectó críticamente el confort térmico de los cerdos, como lo demuestra el aumento de la temperatura de la piel de los cerdos $\left(1,56{ }^{\circ} \mathrm{C}\right.$ y $1,64{ }^{\circ} \mathrm{C}$ de los cerdos de Granja 2 y Granja 1, respectivamente). Los cerdos han alcanzado el límite superior de la zona de temperatura en condiciones de clima cálido. De esta forma, un control microclimático adecuado durante la gestión de los procedimientos pre-sacrificio puede mejorar el bienestar de los cerdos. Para mejorar el confort térmico de los animales, ambas granjas deben reprogramar las operaciones de transporte para las horas más frescas del día. Las granjas también deben mejorar los procesos de gestión pre-sacrificio a través de la capacitación de los empleados para cumplir con los requisitos de bienestar animal y reducir las pérdidas.

Palabras clave: Bienestar animal; Ganadería; Confort térmico; Microambiente de camiones.

\section{Introduction}

Animals interact directly with their rearing environment and respond physically and behaviorally to harsh conditions (Brown-Brandl et al., 2012; Renaudeau et al., 2012; Fox et al., 2014). Pig production in hot and warm regions requires environmental control investments to meet animal welfare standards. Farmers plan their management activities based on weather conditions and animal characteristics such as age, health conditions, and management. By controlling the environment, farmers can help their animals maintain thermoregulation and increase productivity (Renaudeau et al., 2011).

Over the last two decades, the average environmental temperature in tropical countries such as Brazil has varied more widely than in previous decades (INMET, 2015). The consequences of climate change and its consequences, such as heatwaves, might endanger future livestock production (Naas et al., 2010). Animals in developing countries are usually reared in sideopened systems relying on regional weather during reproduction, growing, and fattening (Renaudeau et al., 2011). The cooling systems used in pig production units in Brazil typically combine axial fans and fogging systems and often rely on manual handling by skilled laborers (Sarubbi et al., 2012).

The skin surface temperature is a function of air temperature (the air-skin temperature relationship is linear) (Mcglone et al., 2014). Previous studies show critical loss during transportation to the slaughterhouse when the environmental temperature is above $30{ }^{\circ} \mathrm{C}$ (Haley et al., 2008; Kephart et al., 2014a; Mcglone et al., 2014). The pigskin temperature might also depend on the truck microenvironment (temperature, RH, and WS) and other variables (stock density, physical efforts, fighting among the animals, and heart rate), the truck design, and the animals' locations inside the truck (Correa et al., 2014; Mcglone et al., 2014). The truck microenvironment depends on the location, time, and season of the transport and is affected by extreme air temperature, RH, and WS conditions (Mcglone et al., 2014). Stocking density, animal size, the noxious gas concentration, and the truck parts' 
materials might also impair the safe transportation of pigs (Marahrens et al., 2011; Schwartzkopf-Genswein et al., 2012; Fox et al., 2014; Dalla Costa et al., 2017).

Growing and finishing managements and pre-slaughter process are planned to meet the animal welfare guidelines, which is a demand in the swine market (Trienekens and Wognum, 2013). The trailer design can affect animal handling during transportation, the microenvironmental conditions, and the bruising and injury rate. In Brazil, pigs are transported on single or double-decker wooden open-top trucks, double-decker open-side roofed metal trucks, and triple-decker open-side roofed metal trucks (Triel-HT, 2016). Compassionate transportation relieves the animals' suffering, improves their welfare, meets the quality requirements, reduces losses, and increases the pork supply chain profits (Dalla Costa et al., 2019b). There is information on handling pigs during transportation to the slaughterhouse in developed countries (Hakansson et al., 2016; Dalla Costa et al., 2019a); however, there is a gap in the literature related to these procedures in tropical countries. Therefore, the present study evaluates the impact of two different weather on the thermal comfort of pigs during the pre-slaughter logistics (PSL).

\section{Methodology}

In order to evaluate the impact of two different weathers on the thermal comfort of pigs during the pre-slaughter logistics, we proceded with a qualitative and quantitative research applying a Multiple Case designed based on collect data from an experiment conduct in two farms during pig transportation from farm to slaughterhouse. The animals were observerd during loading, journey and unloading as explained in topic 2.1 and 2.2. Qualitative and quantitative research allow to better understand and explore the phenomenon that it is limited when to use just one method (Martins, 2012). To conduct this paper, we based on previus studies, such as: McGlone et al. (2014), Kephart et al. (2014a), Kephart et al. (2014b), Correa et al. (2014) and Dalla Costa et al. (2017).

Data collection took place in two commercial pig farms in southeastern Brazil located in Espírito Santo state (Farm 1,

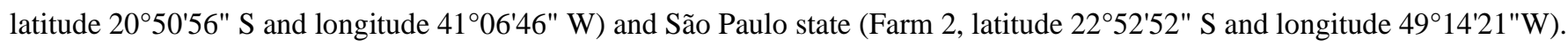
Farm 1 has a tropical climate with an average annual temperature of $23.6^{\circ} \mathrm{C}$ and a rain index of 1200 . Both farms were located in a region with two distinct seasons, dry from April to September and rainy from October to March (INCAPER, 2020). Farm 2 has a tropical climate with an annual average temperature of $20.8^{\circ} \mathrm{C}$ and a rain index of $1353 \mathrm{~mm}$ with hot and dry winters (EMBRAPA, 2020). Farm 1 is an independent producer with a sales contract with a local slaughterhouse, and Farm 2 is an integrated system controlled by a supermarket chain in São Paulo state.

\subsection{Pre-slaughter transport}

In the present study, we monitored two pig shipments between the farm and the slaughterhouse, one for each farm. Both follow the same flow shown in Figure 1. 
Figure 1: Flowchart of pig transportation from the farm to the slaughterhouse.

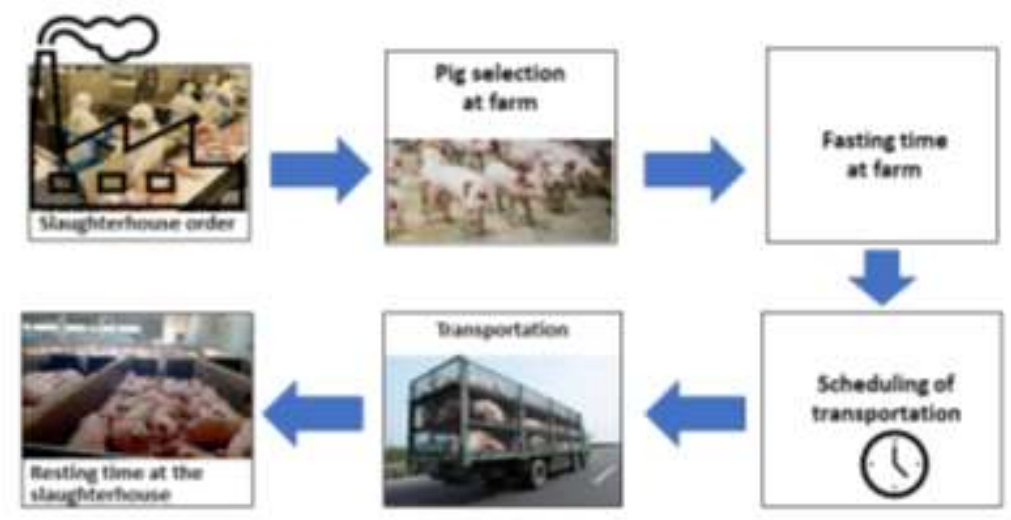

Source: Authors (2021).

The selected animals fasted for six hours before boarding the truck, and while waiting for boarding, they had access to drinking water (Dalla Costa et al., 2019a). The farmer provides the vehicle, the stocking density, and the transport documentation. The transport stocking density is calculated using Equation 1.

$$
\mathrm{D}=\frac{\mathrm{P} \times \mathrm{N}}{\mathrm{A}}
$$

where $\mathrm{D}=$ stocking density $\left(\mathrm{kg} / \mathrm{m}^{2}\right), \mathrm{P}=$ mean pig weight, $\mathrm{N}=$ number of pigs, and $\mathrm{A}=$ body truck area $\left(\mathrm{m}^{2}\right)$. The calculated density was $251.0 \mathrm{~kg} / \mathrm{m}^{2}$ in Farm 1 and $245.0 \mathrm{~kg} / \mathrm{m}^{2}$ in Farm 2.

Finishing pigs (230 Landrace and White Large hybrids) were transported according to the slaughterhouse demand, and 144 were used to evaluate the body truck's microclimate. Table 1 details the operation.

Table 1: Characteristics of the vehicles and trasnportation.

\begin{tabular}{lcclcc}
\hline Characteristics & Farm 1 & Farm 2 & Characteristics & Farm 1 & Farm 2 \\
\hline Body truck & Wood & Steel & Compartments & 4 & 16 \\
Platform & Fixed & Fixed & Length $(\mathrm{m})$ & 7 & 16 \\
Net weight $(\mathrm{t})$ & 8.61 & 19.3 & Width $(\mathrm{m})$ & 2.45 & 2.45 \\
Total area $\left(\mathrm{m}^{2}\right)$ & 17.2 & 39.2 & Ventilation & Natural & Natural \\
Compartment area $\left(\mathrm{m}^{2}\right)$ & 8.6 & 4.9 & Total of pigs & $70^{*}$ & $160^{+}$ \\
Floors & 2 & 2 & Density $\left(\mathrm{kg} / \mathrm{m}^{2}\right)$ & 251 & 245 \\
\hline
\end{tabular}

* 52 pigs were observed in Farm 1 from total; ${ }^{+92}$ pigs were observed in Farm 2 from total. Source: Authors (2021)

The estimated pigs' growth cycle in Farm 1 and Farm 2 was and 156 and 160 days, respectively, with average slaughter weights of $123.0 \mathrm{~kg}$ and $120.6 \mathrm{~kg}$. The pigs from Farm 1 were transported in a double-decker open-top wooden truck (7.00 m long and $2.45 \mathrm{~m}$ wide). The two floors were divided into two compartments. The pigs from Farm 2 were transported in a doubledecker open-side roofed metal truck ( $16.00 \mathrm{~m}$ long and $2.45 \mathrm{~m}$ wide), with eight compartments per floor. The stocking densities were 0.40 and $0.41 \mathrm{~m}^{2} / \mathrm{pig}$, respectively. During loading, the pigs from Farm 1 were guided in groups of six at a loading time of $2.06 \mathrm{~min} /$ group, while in Farm 2, pigs were guided in groups of ten, requiring $2.46 \mathrm{~min} / \mathrm{group}$. In both farms, the pigs were 
loaded in the afternoon, at $13 \mathrm{~h} 11 \mathrm{~min}$ and $13 \mathrm{~h} 47 \mathrm{~min}$, respectively. During loading, the pigs received water sprinkling to alleviate heat stress. After loading, the whole truck was watered to cool down the pigs.

The research was carried out by observing the animals and recording the data without interfering with the animals' routine. The study was approved by the Institutions' Committee on Animal Research, protocol n. 321/15.

\subsection{Variables recorded and experimental procedure}

The recorded variables were the dry-bulb temperature $\left(\mathrm{Ta},{ }^{\circ} \mathrm{C}\right)$, the relative humidity $(\mathrm{RH}, \%)$, the wind speed (WS, $\mathrm{m} / \mathrm{s}$ ), the skin temperature of the finishing pigs $\left(\mathrm{ST},{ }^{\circ} \mathrm{C}\right)$. The temperature-humidity index (THI) was calculated using Equation 2 (Roller and Goldman, 1969), and the bioclimatic index (BI) was estimated using Equation 3 (Texier et al., 1979).

$\mathrm{THI}=0.45 \mathrm{wbt}+1.35 \mathrm{Ta}+32$

where wbt $=$ wet bulb temperature $\left({ }^{\circ} \mathrm{C}\right)$.

$\mathrm{BI}=0.89 \mathrm{Ta}+0.05 \mathrm{RH}-1.81 \mathrm{WS}+0.02 \mathrm{~W}-21.15$

where $\mathrm{W}=$ weight of the pigs $(\mathrm{kg}), \mathrm{Ta}=$ dry-bulb temperature $\left({ }^{\circ} \mathrm{C}\right), \mathrm{RH}=$ relative humidity $(\%)$.

The environment temperature and relative humidity ( $\mathrm{AT}$ and $\mathrm{RH}$ ) inside the truck were monitored during the three phases of transportation (1) loading at the farm, (2) the journey inside the truck and, (3) unloading at the slaughterhouse. Ta and RH's variations were recorded using a data logger (Testo model 172H, Testo Co., Germany) installed in the center of the truck body and recording data every $5 \mathrm{~min}$. The WS was registered using an anemometer (Krestel, Nielsen-Kellerman Co., USA). The environmental data were recorded every $5 \mathrm{~min}$ (Mcglone et al., 2014). The pigskin temperature was registered by a thermal infrared camera (Testo model 875, Testo Co., Germany), the emissivity index was set to 0.95 on all pictures (Brown-Brandl et al., 2012). Thermal infrared images were taken from both laterals of the truck body, targeting the pigs during the loading, travel, and unloading phases. During loading, mid-journey, and unloading, the thermal images were registered (before the truck started moving) and after arrival at the slaughterhouse. The mid-journey distance was $22.5 \mathrm{~km}$ for pigs from Farm 1 and $30 \mathrm{~km}$ for pigs from Farm 2.

\subsection{Statistical analysis}

The PSL (loading, journey, and unloading, and the climate conditions at pig Farm 1 and 2) effects on the pigskin temperature were analyzed. The statistical analysis was based on the following mathematical model (Banzatto and Kronka, 2006, Equation 4):

$$
\text { Yijr }=\mu+\mathrm{TAi}+\mathrm{CCj}+\varepsilon \mathrm{ijr}
$$

Y $i j r$ is a variable dependent on Ta, RH, WS, THI, and BI, $\mu$ is the general average, TA $i$ and $\mathrm{CC} j$ represent the effects of transport activity $i$ and climate condition $j$, respectively $\varepsilon i j r$ is the random error in each observation. The ANOVA was applied using a general linear model, and the Tukey test was performed using the software SAS $\odot$, version 9.0, adopting a confidence level of 0.95 in all analyses.

\section{Results}

$\mathrm{Ta}$ and $\mathrm{BI}$ results during the loading, journey and unloading management differed among the studied farms $(\mathrm{P}<0.05)$. The bioclimatic index (BI) estimates the pigs' thermal comfort more accurately than the THI, probably because the BI calculation 
includes the WS variation. RH affected the length of the journey than the other studied activities $(\mathrm{P}<0.05)$. Both the loading process and the journey had similar effects on the pigskin temperature $(\mathrm{P}<0.05)$ (Table 2).

Table 2: Average air temperature $\left(\mathrm{T}_{\mathrm{a}}\right.$ ), relative humidity (RH), wind speed (WS), pigskin temperature (ST), temperaturehumidity index (THI), and bioclimatic index (BI) during each transportation activity.

\begin{tabular}{rccc}
\hline Variables & Loading & Journey & Unloading \\
\hline $\mathrm{n}$ & 59 & 50 & 35 \\
$\mathrm{~T}_{\mathrm{a}}\left({ }^{\circ} \mathrm{C}\right)$ & $30.6 \pm 0.1^{\mathrm{a}}$ & $29.1 \pm 0.1^{\mathrm{b}}$ & $28.4 \pm 0.1^{\mathrm{c}}$ \\
$\mathrm{RH}(\%)$ & $60.4 \pm 0.7^{\mathrm{b}}$ & $59.0 \pm 0.9^{\mathrm{a}}$ & $60.4 \pm 1.0^{\mathrm{b}}$ \\
$\mathrm{WS}(\mathrm{m} / \mathrm{s})$ & - & $0.86 \pm 0.0$ & - \\
$\mathrm{ST}\left({ }^{\circ} \mathrm{C}\right)$ & $31.7 \pm 0.2^{\mathrm{a}}$ & $33.1 \pm 0.3^{\mathrm{a}}$ & $29.0 \pm 0.3^{\mathrm{b}}$ \\
$\mathrm{THI}$ & $83.7 \pm 0.2^{\mathrm{a}}$ & $81.1 \pm 0.2^{\mathrm{b}}$ & $79.7 \pm 0.2^{\mathrm{b}}$ \\
$\mathrm{BI}$ & $11.5 \pm 0.1^{\mathrm{a}}$ & $8.56 \pm 0.1^{\mathrm{c}}$ & $9.6 \pm 0.1^{\mathrm{b}}$
\end{tabular}

a, b, c are significance indicators. Means with the same letter in the same line do not differ by the Tukey test $(\mathrm{P}>0.05) ; \mathrm{n}$ = number of pigs. Source: Authors (2021).

During transport from Farm 1, the Ta and RH ranges were $33.2-41.4^{\circ} \mathrm{C}$ and $27.8-57.6 \%$, respectively, and the pigskin temperature fluctuated from 34.8 to $40.3^{\circ} \mathrm{C}$ (amplitude $=5.5{ }^{\circ} \mathrm{C}$ ). The pigs transported from Farm 2 were exposed to Ta, ranging from 18.8 to $24.8^{\circ} \mathrm{C}$ and $\mathrm{RH}$, ranging from 74.8 to $95.7 \%$. The pigskin temperature fluctuated between 17.7 and $33^{\circ} \mathrm{C}$ (amplitude $\left.=15 \cdot 3{ }^{\circ} \mathrm{C}\right)$.

The surface temperature of the pigs was positively correlated with Ta, THI, and BI, with correlation coefficients of $0.8474,0.8352$, and 0.7867 , respectively (all $\mathrm{P}<0.05$ ), and was negatively correlated with $\mathrm{RH}(-0.8178, \mathrm{P}<0.05)$. The THI and BI were positively correlated with $\mathrm{Ta}$ (respective correlation coefficients of 0.9954 and 0.91 ; both $\mathrm{P}<0.05$ ) and negatively correlated with RH $(-0.8028$ and -0.7187 , respectively; both $\mathrm{P}<0.05)$. Therefore, ST increased when Ta, THI, and BI increased and reduced by increasing RH.

\subsection{Thermal comfort of pigs during pre-slaughter management}

On the day of the transportation to the slaughterhouse, the weather conditions at Farm 2 were more favorable for the pigs' thermal comfort than those at Farm 1. During PSL management at Farm 2, the THI increased from 65.5 to 76.0 (amplitude $=10.5^{\circ} \mathrm{C}$ ), and the pigskin temperature increased by $8.16^{\circ} \mathrm{C}$. At Farm 1, the THI rose from 87.3 to $100.2\left(\right.$ amplitude $=12.9^{\circ} \mathrm{C}$ ), and the pigskin temperature decreased by $0.1^{\circ} \mathrm{C}$. The pigs transported from Farm $2(90.2 \%)$ were in a thermally neutral environment (THI<75), and 9.8\% reached the alert to the critical thermal comfort zone (THI 75-79). All pigs transported from Farm 1 were in the emergency zone, exposed to acute thermal stress (THI>83; Table 3). Although the skin temperature followed the increase in THI at Farm 2, it decreased at Farm 1 despite the increased THI. One interpretation of this result is the activation of a survival characteristic in the pigs that maintains a constant core body temperature. 
Table 3: Average, standard deviation, and range of pigs' surface temperature $\left({ }^{\circ} \mathrm{C}\right)$ for different THI during PSL at Farm 1 and Farm 2.

\begin{tabular}{cccccc}
\hline Farm 2 THI & $\mathrm{n}$ & Average $\left({ }^{\circ} \mathrm{C}\right)$ & $\mathrm{SD}\left({ }^{\circ} \mathrm{C}\right)$ & Minimum $\left({ }^{\circ} \mathrm{C}\right)$ & Maximum $\left({ }^{\circ} \mathrm{C}\right)$ \\
\hline $65<68^{*}$ & 16 & $20.36^{\mathrm{c}}$ & 2.57 & 17.7 & 27.7 \\
$68<71^{*}$ & 33 & $25.37^{\mathrm{b}}$ & 2.42 & 20.0 & 29.3 \\
$71<74^{*}$ & 34 & $27.86^{\mathrm{a}}$ & 2.65 & 22.9 & 33.0 \\
$>74^{* *}$ & 9 & $28.52^{\mathrm{a}}$ & 2.89 & 24.4 & 31.7 \\
\hline Farm 1 THI & $\mathrm{n}$ & Average $\left({ }^{\circ} \mathrm{C}\right)$ & $\mathrm{SD}\left({ }^{\circ} \mathrm{C}\right)$ & Minimum $\left({ }^{\circ} \mathrm{C}\right)$ & Maximum $\left({ }^{\circ} \mathrm{C}\right)$ \\
\hline $87<90^{++}$ & 7 & 37.7 & 1.95 & 35.2 & 39.9 \\
$90<93^{++}$ & 21 & 38.5 & 1.05 & 36.6 & 40.3 \\
$93<96^{++}$ & 10 & 37.5 & 1.25 & 35.9 & 39.5 \\
$>96^{++}$ & 14 & 37.6 & 1.45 & 34.8 & 39.5
\end{tabular}

a, b, c, d are the significance indicators. The same letter in the same column means that the results do not significantly differ by the Tukey test $(\mathrm{P}>0.05) ; \mathrm{n}=$ number of pigs observed at the given $T H I ; \mathrm{SD}=$ standard deviation. * thermal comfort $(>75)$; ${ }^{* *}(75-79)$ alert, critical thermal comfort; ${ }^{+}(79-83)$ danger, critical thermal stress; and ${ }^{++}(>83)$ emergency, very acute thermal stress (Barbari and Conti, 2009). Source: Authors (2021).

The BI ranged from 11.5 to 19.9 (amplitude $=8.4$ ) at Farm 1, and from 1.12 to 6.95 (amplitude $=5.8$ ) at Farm 2. The BI at both farms was higher during loading than transportation or unloading. However, the pigs' surface temperature rose sharply (by $1.0^{\circ} \mathrm{C}$ and $1.4{ }^{\circ} \mathrm{C}$, at Farm 1 and Farm 2, respectively) during the journey (Table 4). At Farm 2, the BI reduced throughout the PSL activities, from 4.8 during loading to 3.4 while unloading (amplitude $=1.4$ ). However, BI decreased 5.4 from loading to journey during PSL at Farm 1 but increased 2.9 from the journey to unloading.

Table 4: Average, standard deviation, and range of pigs' skin temperature $\left({ }^{\circ} \mathrm{C}\right)$ and bioclimatic index (BI) during PSL activities at Farm 1 and Farm 2.

\begin{tabular}{|c|c|c|c|c|c|c|c|c|}
\hline \multirow[b]{2}{*}{ PSL } & \multicolumn{4}{|c|}{ Farm 1} & \multicolumn{4}{|c|}{ Farm 2} \\
\hline & BI & & $\mathrm{ST}\left({ }^{\circ} \mathrm{C}\right)$ & & BI & & $\mathrm{ST}\left({ }^{\circ} \mathrm{C}\right)$ & \\
\hline Loading & $\begin{array}{c}\mathrm{Avg} \pm \mathrm{SD} \\
18.2 \pm 1.2\end{array}$ & $\begin{array}{c}\text { Range } \\
16.6-19.8\end{array}$ & $\begin{array}{c}\text { Avg } \pm \text { SD } \\
37.1 \pm 2.6\end{array}$ & $\begin{array}{c}\text { Range } \\
34.8-39.5\end{array}$ & $\begin{array}{c}\text { Avg } \pm \text { SD } \\
4.8 \pm 0.7\end{array}$ & $\begin{array}{l}\text { Range } \\
3.9-6.3\end{array}$ & $\begin{array}{c}\mathrm{Avg} \pm \mathrm{SD} \\
26.4 \pm 1.1\end{array}$ & $\begin{array}{c}\text { Range } \\
22.9-29.3\end{array}$ \\
\hline Journey & $12.8 \pm 0.7$ & 11.4-13.9 & $38.1 \pm 1.7$ & $35.2-40.3$ & $4.2 \pm 1.5$ & $1.1-6.9$ & $27.8 \pm 2.8$ & $24-33$ \\
\hline Unloading & $15.7 \pm 0.0$ & $15.7-15.8$ & $38.0 \pm 0.8$ & $36.6-39.2$ & $3.4 \pm 0.6$ & $2.7-4.5$ & $19.9 \pm 1.2$ & $17.7-21.6$ \\
\hline
\end{tabular}

Source: Authors (2021).

\subsection{Loading, journey from the farm to the slaughterhouse and Unloading}

During loading, transport, and unloading, the pigs from Farm 1 were exposed to more variable temperatures than Farm 2. The ambient dry-bulb temperature increased by $4.1{ }^{\circ} \mathrm{C}$ during the first 20 minutes of the journey from Farm 1 to the slaughterhouse. After the water sprinkling process, the temperature decreased by $8.2^{\circ} \mathrm{C}$ but then gradually climbed by $2.5{ }^{\circ} \mathrm{C}$. During unloading, the dry-bulb temperature increased by $1.0^{\circ} \mathrm{C}$. On the other hand, during the first 20 minutes after loading from Farm 2, the dry-bulb temperature decreased $2.1^{\circ} \mathrm{C}$, and then gradually increased $1.7^{\circ} \mathrm{C}$. The initial decline in air temperature resulted from the evaporative cooling effect of the sprinkling water before and after loading. During transportation, the air temperature varied from 20 to $24.8^{\circ} \mathrm{C}$ (averaging $22.8^{\circ} \mathrm{C}$ ). The air temperature was slightly higher during the first 30 minutes 
of transport than after 85 minutes. After 85 min of transportation, the air temperature had gradually decreased by $4.2^{\circ} \mathrm{C}$. During unloading, the air temperature was further reduced by $2.0^{\circ} \mathrm{C}$.

The dry-bulb temperature increased while loading the pigs at Farm 1. During the loading, it varied from 37.7 to $41.4{ }^{\circ} \mathrm{C}$. The surface temperature of the pig skins also rose $1.27^{\circ} \mathrm{C}$ during loading. The temperature rise was credited to the overcrowding of pigs in the truck, but the sprinkling process did not begin 20 minutes later. On the other hand, the temperature decreased during loading at Farm 2 and varied from 20.8 to $22.9{ }^{\circ} \mathrm{C}$, implying a $0.80{ }^{\circ} \mathrm{C}$ reduction of the pigs' surface temperature (Figure 2). Unlike the Farm 1 counterpart, the pigs from Farm 2 were sprinkled before loading, and the whole truck was watered. After loading the pigs into the truck, the handlers applied a second water sprinkling. The decrease in the temperature readings during loading was attributed to the first sprinkling process. In both farms, the loading process was performed quickly (0.24 min per animal at Farm 1 and 0.34 and Farm 2, respectively).

Figure 2: Average air temperature (Ta) and pig skin temperature (ST) during loading, the journey and unloading.

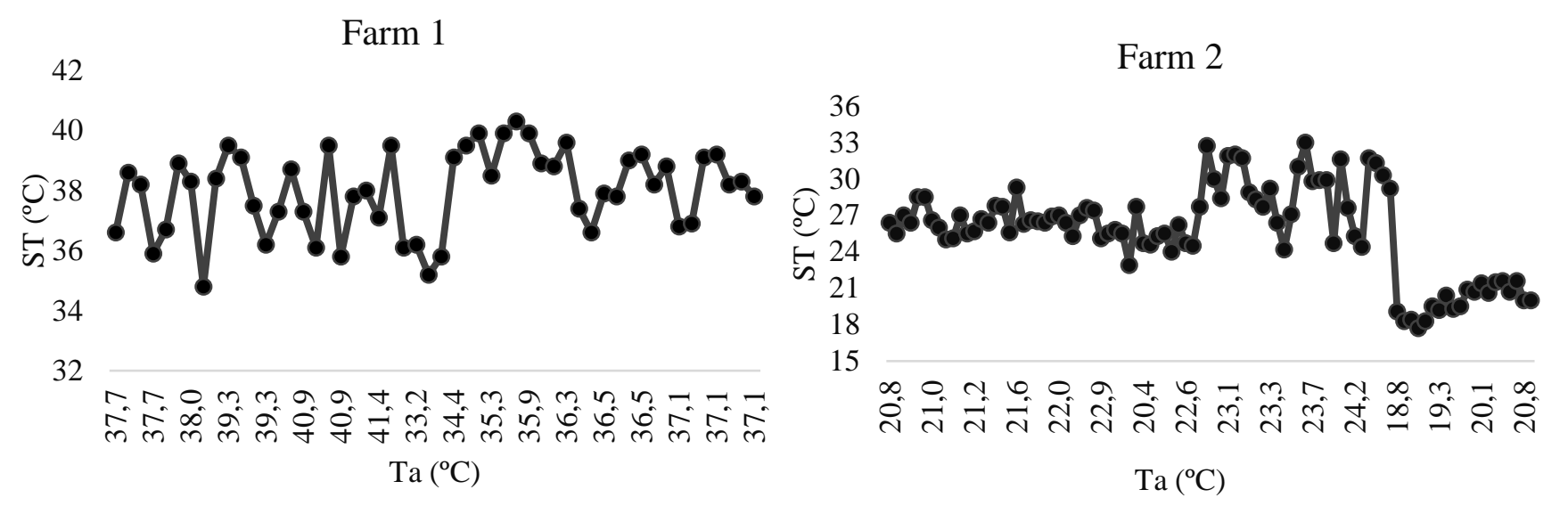

Source: Authors (2021).

During pig transportation, the temperature increased from 33.2 to $36.3{ }^{\circ} \mathrm{C}$ at Farm 1 and 20 to $24.8{ }^{\circ} \mathrm{C}$ at Farm 2 . The pigskin temperature increased by $1.56{ }^{\circ} \mathrm{C}$ from Farm 2 and $1.64{ }^{\circ} \mathrm{C}$ from Farm 1 during transport. In addition, during the unloading process, the air temperature ranged from 36.8 to $37.2^{\circ} \mathrm{C}$ at Farm 1 and 18.8 to $20.8{ }^{\circ} \mathrm{C}$ at Farm 2 (Figure 2). During unloading at the slaughter plant in Farm 1, the pigs' skin surface temperature decreased by $0.25^{\circ} \mathrm{C}$ because the sprinkling process was applied shortly before unloading. In contrast, the skin surface temperature of pigs unloaded in the Farm 2 region increased by $1.45^{\circ} \mathrm{C}$. The findings of the present study reflect the time and the handling applied during the unloading process. The pigs from Farm 1 were unloaded by two workers; while one handler wetted the pigs, the other opened the truck door and encouraged them out of the truck. Pigs from Farm 2 were handled by a single worker who opened the truck and waited for them to exit. If the pigs remain in the truck after 10 minutes, the employee began stimulating them to leave the truck.

\section{Discussion}

In the present study, we evaluated the impact of two different weather on the thermal comfort of pigs during the preslaughter. The whole process was done in the afternoon when the temperature is high in the tropical climate. The association of high temperature and high relative humidity is detrimental to pigs (Brown-Brandl et al., 2012). Large variations in air temperature affect the thermal comfort of pigs and compromise meat quality (Ludtke et al., 2010). Loading is considered a stressful action during PSL, as it exposes the animals to an unfamiliar environment. In the Brazilian animal welfare guidelines, the stocking 
density is limited to $230 \mathrm{~kg} / \mathrm{m}^{2}$ or $0.43 \mathrm{~m}^{2} / \mathrm{pig}$ (Dias et al., 2011). The stocking density is also restricted in Canada, European countries, and the United States (Correa et al., 2014; Kephart et al., 2014a), under different climatic conditions. SchwartzkopfGenswein et al. (2012) suggested that lowering the loading stocking density in warmer temperatures would reduce the heat stress and improve animal welfare during transport. The use of sprinkling water during loading was beneficial to the pigs. Fox et al. (2014) also measured the truck ambient temperature during the departure and unloading processes using sprinklers and reported a similar result.

We found an increase in ambient temperature and pigskin temperature during the journey. Kephart et al. (2014a) found that the pigskin temperature ranged from 29.3 to $36.2{ }^{\circ} \mathrm{C}$ (amplitude $=6.9{ }^{\circ} \mathrm{C}$ ) and from 30.1 to $38.7{ }^{\circ} \mathrm{C}\left(\right.$ amplitude $=8.6{ }^{\circ} \mathrm{C}$ ), respectively. In the present study, during loading, the pigskin temperature presented a varying amplitude from $15.3^{\circ} \mathrm{C}$ to $5.5^{\circ} \mathrm{C}$, a broader range than previously studied. Results from the current study suggest that during the journey, the BI is affected by wind speed. Consequently, the BI varied more at Farm 1 than at Farm 2. A near-zero BI indicates that the ambient temperature is close to the thermal neutral zone, whereas large BIs indicate harsh thermal conditions (Texier et al., 1979). According to Texier et al. (1979), a BI between 0 and 4 (temperature $17-21^{\circ} \mathrm{C}$ ) favors good animal performance. Pigs transported from the Farm 2 were within the thermal comfort zone, but those transported from Farm 1 were exposed to thermal stress.

We found a positive correlation between pigskin temperature and Ta, THI, and BI. Pigskin temperature rises when Ta, THI, and BI increases and reduces when RH increases. Similarly, Kephart et al. (2014a) reported an increase in the pigs' skin temperature after the THI increased during warm and hot weather. During loading, the pigs' heart rate is higher in summer than in winter (Correa et al., 2014). Loading activity is associated with distress factors such as transfer from a familiar to an unfamiliar environment, the presence of ramps, physical effort, human interaction, increased density, and trailer design. Correa et al. (2014) propose an association of the high heart rate of pigs waiting for loading during summer with the physical effort of accessing the truck compartments. The increased heart rate might raise the blood flow to the skin, increasing the skin temperature (Kephart $e t$ al., 2014b); therefore, the skin temperature rise observed in the present study could be due to both the increase in ambient temperature and the pigs' physiological response to the loading and transportation distress.

The pigs' thermal comfort was similar in both transport scenarios. The journey's length is associated with many stressors, such as truck vibration, road paving, and exposure to sun and rain (Ludtke et al., 2010). Haley et al. (2008) found that temperatures above $30^{\circ} \mathrm{C}$ increase the losses during transport, indicating that pigs transported from Farm 1 presented more loss risk to the pork industry than those transported from Farm 2. The transport time from Farm 2 was similar to the 138 min reported by Kephart et al. (2014b). In European law, the transportation time of animals is limited to $8 \mathrm{~h}$. The Canada welfare code specifies that animals intended for a trip exceeding $12 \mathrm{~h}$ must have access to feed and water during the journey (FAWC, 2009). Such a procedure is quite challenging in continental countries as Canada and Brazil.

Whether the decrease in air temperature during pre-slaughter transportation was more delayed under Farm 2 conditions than under Farm 1 is not clear by the present results. However, applying the sprinkling process at the moment of temperature increase, as implemented at Farm 1, was efficient.

Although transported pigs can adapt to the process, the animals are exposed to several risks, such as inappropriate floor surfaces, overcrowding, and inexperienced handlers risk injuries such as bruising, wounds, and fractures. Other aggravating risk factors are dehydration from lack of drinking water and aggression when mixing with new animals (Marahrens et al., 2011). These unsafe conditions incur losses in the Brazilian pork industry. The loading, transport, and unloading processes almost double the skin injury rate relative to resting periods (Dalla-Costa et al., 2019b). Ferguson and Warner (2008) stated that distress is an expected consequence of transferring an animal from farm to slaughter.

The unloading period is stressful for animals. Kephart et al. (2014b) reported an average unloading period of 16 minutes, more than double the unloading period applied by the Farm 1 workers, and less than the unloading period of Farm 2 . The 
unloading distress is related to physical pig effort, the transfer of the pigs from a new environment, human interaction (animal handling and inspection), ramps, the climate conditions at the slaughter plant, and industrial machinery's noise. Pigs become agitated during unloading, causing additional losses. According to Kephart et al. (2014b), bedding can minimize the distress signs during pigs' transportation.

Poor transportation conditions lead to low meat quality and increased loss (Kephart et al., 2014b), as well as the inadequate pre-slaughter period, disrupts the animals' homeostasis, triggering an adaptive response that restores the thermal balance (Ferguson and Warner, 2008). Such combined stressors might degrade the animals' welfare and meat quality posttransport (Schwartzkopf-Genswein et al., 2012). Fear, dehydration, and hunger increase physical activity, and pre-slaughter management can fatigue and injure the animals (Ferguson and Warner, 2008). Pig transportation planning must overcome several problems, such as meeting animal welfare standards, ensuring consumers' health, and satisfying traceability and sustainability demands (Marahrens et al., 2011; Trienekens and Wognum, 2013). During transportation, pigs are exposed to several distress factors. Variations in these factors can disturb the animals' behavior and compromise the meat quality and contribute to losses in the pork industry (Dalla Costa et al., 2017). Strategic planning using the best solutions for animal transportation has promising improvement in animal welfare, as it may reduce transportation time (Hakansson et al., 2016).

Companies involved in the meat industry can reduce animal stress by following the pre-slaughter recommendations of animal welfare standards and observing best animal handling practices during the PSL process. As a balance between economic restrictions and animal welfare standards, they recommended shipping the pigs at night. Fox et al. (2014) also reported the reduced welfare and increased losses incurred by stressful conditions during pig transport. Previous studies have also recommended rescheduling transport to the coolest time of the day (Ludtke et al., 2010; Marahrens et al., 2011; SchwartzkopfGenswein et al., 2012). Improving the transportation conditions and reducing losses and providing proper animal welfare will likely improve the quality of meat sold to customers (Trienekens and Wognum, 2013).

\section{Conclusion}

Pigs in hot climates are exposed to heat stress, often reaching the thermoneutral zone's critical upper limit. Handlers should control the ambient dry-bulb temperature, which is the primary step of the pre-slaughter logistic to improve the animal welfare conditions. Among the loading, transportation, and unloading activities, the journey presents the most significant hazard to pigs transported towards the slaughterhouse. Adequate control of the truck microclimate might increase the pork quality by reducing thermal stresses. The results of this case study indicate that rescheduling transportation from afternoon to morning or night would improve the pre-slaughter management methods, as proposed in previous studies. By adopting compassionate preslaughter processes results in an improvement in the wellbeing of the animals and reduce losses to the industry.

This paper showed the importance to reduce microclimate truck thermal stress during pre-slaughter logistics; however, it is necessary new studies that integrated the pre-slaughter logistics parameters and thermal comfort with carcass yield to evaluate the financial impact on pork industry.

\section{Acknowledgments}

To Coordination of Improvement of Higher Education (CAPES) for the research grant.

\section{References}

Banzatto, D. A \& Kronka, S. N. (2006). Experimentação agrícola [Agricultural Experimentation]. FUNEP.

Barbari, M. \& Conti, L. (2009). Use of different cooling systems by pregnant sows in the experimental pen. Biosystems Engineering, 103 (2), $239-244$. 
Brown-Brandl, T. M., Eigenberg, R.A. \& Purswell, J. L. (2012). Determining heat tolerance in finishing pigs using thermal imaging. In: Cambra-Lopez, M., Wheeler, E. F., Moura, D. J., Janni, K. \& Gates, R. S. (2012). Proceedings of the 9th International Livestock Environment Symposium (ILES IX), Paper 39. ASABE, 2012 July 8-12, Valencia (Spain).

Correa, J. A., Gonyou, H., Torrey, S., Widowski, T., Bergeron, R., Crowe, T., Laforest, J-P. \& Faucitano, L. (2014). Welfare of pigs being transported over long distances using a pot-belly trailer during winter and summer. Animals, 4 (2), 200-213.

Dalla Costa, F.A., Lopes, L.S. \& Dalla Costa, O.A. (2017). Effects of the truck suspension system on animal welfare, carcass and meat quality traits in pigs. Animals, 7 (1), 5-18.

Dalla Costa, F. A., Dalla Costa, O. A., Coldebella, A., de Lima, G. J. M. M. \& Ferraudo, A. S. (2019a). How do season, on-farm fasting interval and lairage period affect swine welfare, carcass and meat quality traits? International Journal of Biometeorology, 63, 1497-1505

Dalla Costa, O. A., Dalla Costa, F. A., Feddern, V., dos Santos, L. L., Coldebella, A., Gregory, N. G. \& de Lima, G. J. M. M. (2019b). Risk factors associated with pig pre-slaughtering losses. Meat Science, 155, 61-68.

Dias, A. C., Carraro, B. Z., Dallanora, D., Coser, F. J., Machado, G. S., Machado, I. P., Pinheiro, R. \& Rohr, S. A. (2011). Manual brasileiro de boas práticas agropecuária na produção de suínos [Best-Practices in Brazilian agricultural and production of pigs]. Brasília: ABCS, MAPA, EMBRAPA Suínos e Aves.

EMBRAPA, Empresa Brasileira de Pesquisa Agropecuária. (2015). Condições meteorológicas [Meteorological conditions]. http://www.cppse.embrapa.br/dados-meteorologicos

FAWC, Farm Animal Welfare Council. (2009). Farm animal welfare in Great Britain: past, present and future. https://www.gov.uk

Ferguson, D.M. \& Warner, R. D. (2008). Have we underestimated the impact of pre-slaughter stress on meat quality in ruminants? Meat Science, 80 (1), 12-19.

Fox, J., Widowski, T., Torrey, S., Nannoni, E., Bergeron, R., Gonyou, H. W., Brown, J. A., Crowe, T., Mainau, E. \& Faucitano, L. (2014). Water sprinkling market pigs in a stationary trailer. 1. Effects on pig behavior, gastrointestinal tract temperature and trailer micro-climate. Livestock Science, 160, 113-123.

Haley, C., Dewey, C. E., Widowski, T., Poljak, Z. \& Friendship, R (2008). Factors associated with in-transit losses of market hogs in Ontario in 2001. Canadian Journal of Veterinary Research, 72 (5), 377-384.

Hakansson, N., Flisberg, P., Algers, B., Jonsson, A., Rönnqvist, M. \& Wennergren, U. (2016). Improvement of animal welfare by strategic analysis and logistic optimisation of animal slaughter transportation. Animal Welfare, 25 (2), 255-263.

INMET, Instituto Nacional de Meteorologia. (2015). Anomalias de temperaturas medias mensais [Monthly average temperature anomalies]. http://www.inmet.gov.br/portal/index.php?r=clima/anomaliaTempMediaMensal

Ludtke, C. B., Silveira, E. T. F., Bertoloni, W., Andrade, J. C., Buzelli, M. L., Bessa, L. R. \& Soares, G. J. D. (2010). Bem-estar e qualidade de carne de suíno submetidos a diferentes técnicas de manejo pré-abate [Welfare and meat quality of pigs submitted to differentt pre-slaughter handling techniques]. Revista Brasileira de Saúde e Produção Animal, 11 (1), 231-241.

Kephart, R., Johnson, A., Sapkota, A., Stalder, K. \& Mcglone, J. (2014a). Establishing sprinkling requirements on trailers transporting market weight pigs in warm and hot weather. Animals, 4 (2), 164-183.

Kephart, R., Johnson, A., Sapkota, A., Stalder, K. \& Mcglone, J. (2014b). Establishing bedding requirements on trailers transporting market weight pigs in warm weather. Animals, 4 (2), 476-493.

Marahrens, M., Kleinschmidt, N., Di Nardo, A., Velarde, A., Fuentes, C., Truar, A., Otero, J. L., Di Fede, E. \& Dalla Villa, P. (2011). Risk assessment in animal welfare-especially referring to animal transport. Preventive Veterinary Medicine, 102 (2), 157-163.

Martins, R. A. (2012). Abordagens quantitativa e qualitativa [Quantitative and Qualitative Approaches]. In: Miguel, P. A. C. (Org.). Metodologia de pesquisa para engenharia de produção e gestão de operações (47-63). Rio de Janeiro: Elsevier.

McGlone, J., Johnson, A., Sapkota, A. \& Kephart, R. (2014). Establishing Bedding Requirements during Transport and Monitoring Skin Temperature during Cold and Mild Seasons after Transport for Finishing Pigs. Animals, 4 (2), 241-253.

Naas, I. A., Romanini, C. E. B., Salgado, D. D’A., Lima, K. A. O., Vale, M. M., Labigalini, M. R., Souza, S. R. L., Menezes, A. G. \& Moura, D. J. (2010). Impact of global warming on beef cattle production cost in Brazil. Scientia Agricola, 67 (1), 1-8.

Renaudeau, D., Gourdine, J. L. \& ST-Pierre, N. R. (2011). A meta-analysis of the effects of high ambient temperature on growth performance of growingfinishing pigs. Journal of Animal Science, 89 (7), 2220-2230.

Renaudeau, D., Collin, A., Yahav, S., Basilio, V., Gourdine, J. L. \& Collier, R. J. (2012). Adaptation to hot climate and strategies to alleviate heat stress in livestock production. Animal, 6 (5), 707-728.

Triel-Ht. (2016). Carroceira metálica para transporte suínos-abate [Truck with metal body for pig-slaughter transport]. http://pt.trielht.com.br/logisticaagroindustrial/produtos

INCAPER, Instituto Capixaba de Pesquisa, Assistência Técnica e Extensão Rural. (2020). Programa de assistência técnica e extensão rural [Technical assistance and rural extension program]. Cachoeiro de Itapemirim: MAPA.

Roller, W. L. \& Goldman, R. F. (1969). Response of swine to acute heat exposure. T. ASABE, 12, 164-169.

Sarubbi, J., Rossi, L. A., Moura, D. J., Oliveira, R. A. \& Maia, A. P. A. (2012). Nocturnal thermal comfort in facilities for growing swines. Engenharia Agrícola, $32(6), 1034-1040$. 
Research, Society and Development, v. 10, n. 13, e115101321077, 2021

(CC BY 4.0) | ISSN 2525-3409 | DOI: http://dx.doi.org/10.33448/rsd-v10i13.21077

Schwartzkopf-Genswein, K. S., Faucitano, L., Dadgar, S., Shand, P., Gonzáles, L. A. \& Crowe, T. G. (2012). Road transport of cattle, swine and poultry in North America and its impact on animal welfare, carcass and meat quality: a review. Meat Science, 92 (3), 227-243.

Texier, C., De la Farge, B. \& Granier, R. (1979). Influence des variations des principaux facters de l'ambiance en porcherie d'engraissement [Influence of variations of the main factors of the environment in fattening house]. Jounées de la Recherche Porcine en France, 153-164.

Trienekens, J. \& Wognum, N. (2013). Requirements of supply chain management in differentiating European pork chains. Meat Science, 95 (3), $719-726$. 